\title{
Chapter 21 \\ Making Urban Waste Management and Drainage Sustainable in Nepal
}

\author{
Mani Nepal, Bishal Bharadwaj, Apsara Karki Nepal, Madan S. Khadayat, \\ Ismat Ara Pervin, Rajesh K. Rai, and E. Somanathan
}

\begin{abstract}
Disclaimer: The presentation of material and details in maps used in this book does not imply the expression of any opinion whatsoever on the part of the Publisher or Author concerning the legal status of any country, area or territory or of its authorities, or concerning the delimitation of its borders. The depiction and use of boundaries, geographic names and related data shown on maps and included in lists, tables, documents, and databases in this book are not warranted to be errorfree nor do they necessarily imply official endorsement or acceptance by the Publisher, Editor(s), or Author(s).
\end{abstract}

The original version of this chapter was revised. The correct chapter author names are now listed in order. The correction to this chapter is available at

https://doi.org/10.1007/978-981-16-0680-9_30

\section{Nepal (ه)}

South Asian Network for Development and Environmental Economics (SANDEE), International Centre for Integrated Mountain Development (ICIMOD), Kathmandu, Nepal

e-mail:mani.nepal@icimod.org

B. Bharadwaj

University of Queensland, St. Lucia, 4072 Queensland, Australia

e-mail: s4441329@student.uq.edu.au

\section{A. Karki Nepal}

International Centre for Integrated Mountain Development (ICIMOD), Kathmandu, Nepal e-mail: apsara.nepal@icimod.org

M. S. Khadayat

Kathmandu, Nepal

e-mail: madankdyt@yahoo.com

I. A. Pervin

Institute of Water Modelling, Dhaka, Bangladesh

e-mail: iap@iwmbd.org

R. K. Rai

School of Forestry and Natural Resource Management, Institute of Forestry, Tribhuvan

University, Kathmandu, Nepal 


\section{Key Messages}

- Cities in Nepal are facing urban flooding and waterlogging risks which can be addressed by more investment on constructing drainage systems.

- Without proper solid waste management, the returns from investment on urban infrastructure would be low after few years.

- Additional user fees, revenue from recycling waste and additional import duty on importing plastic raw materials provide enough resources for managing solid waste which helps appreciating urban property prices.

\subsection{Introduction}

Cities in developing countries are facing increasing threats from waterlogging, flooding and water contamination aggravated by improperly managed solid waste. Several factors are responsible: unplanned urban growth has led to expansion of city areas into low-lying flood plains; climate change is leading to intense rainfall events which risk overwhelming city drainage systems; informal dumping sites may result in toxic waste entering rivers and groundwater following heavy rainfall; and indiscriminate dumping of untreated solid waste can clog the drainage system.

Waterlogging and water pollution have a disproportionate impact on the poorest sections who usually live near flood plains or in the slums in the less developed sections of the city (Ahmed, 2016; Sharma et al., 2022, Chap. 22 of this volume). Climate change is likely to exacerbate these problems.

The suffering caused by frequent waterlogging has created public pressure to develop strategies. The most popular strategy is to invest in urban drainage infrastructure in order to eliminate drainage congestion. However, an analysis of the causes of waterlogging illustrates that investment in physical infrastructure alone is not enough (Pervin et al., 2020). Cities also need to work with inhabitants to improve the 'urban culture' of solid waste disposal. This requires a change in behaviour in terms of reduction and disposal of municipal solid waste. Stakeholders' survey from South Asia suggests that South Asians prefer waste-to-energy strategies in order to address municipal solid waste management issue (Haque et al., 2019).

There are several known solutions to this: (a) development or creation of a market for recycling; (b) creating conditions for reuse of waste; (c) developing strategies for reducing the volume of waste; and (d) proper disposal of solid waste. In established cities, waste from businesses and households is collected for a fee while city councils take responsibility for dumpsites, while such a system is absent in many emerging cities in developing countries.

e-mail: rjerung@gmail.com

E. Somanathan

Indian Statistical Institute, New Delhi, India

e-mail: som@isid.ac.in 
After the promulgation of a new Constitution in 2015, Nepal designated more than 220 new municipalities. Several of these new municipalities have no formal waste management system. Even if they have some form of waste collection system (formal or informal), proper management of the collected waste has been another challenge as these cities lack sanitary-landfill sites. Though most have informal and unorganized markets for recycling metal, paper and plastic, they rarely have segregation at source. As a result, informal agents like rag-pickers are engaged in sorting and segregating the tradable products from other wastes at the dumpsite or at the secondary transfer stations. The rag-pickers are often women and children from poor families (Bharadwaj, Baland, \& Nepal, 2020) who are exploited as they are unorganized and not protected by rules or regulations. In addition, they are also exposed to health risks during the process of separating the tradable products.

Against this background, protecting cities require reducing the volume of waste, improving collection systems, investment in drainage, replacing riverside and wetland dumping with engineered landfills and identifying sustainable mechanisms to finance these improvements in waste management for enhancing urban resilience.

In Bharatpur, the informal collection system involves collection from houses and businesses and dumping at designated sites. Rag-pickers use dumpsites to collect recyclable or reusable materials (Rai et al., 2019). The city has no sanitary-landfill site, and hence, there is a further risk of health hazards through water contamination (both surface and underground water aquifers) and foul smell.

This chapter summarizes the key learning from a large-scale research project coordinated by the South Asian Network for Development and Environmental Economics (SANDEE) Secretariat at the International Centre for Integrated Mountain Development (ICIMOD) under the Cities and Climate Change research, ${ }^{1}$ where we: (a) examine the existing situation of waterlogging and flooding in Bharatpur under different climatic scenarios and the contribution of proper solid waste management in avoiding flooding and waterlogging risks, (b) examine the effectiveness of information and waste bins on the streets on cleanliness in Bharatpur, (c) estimate the value of cleaner neighbourhoods in Bharatpur and other urban centres across Nepal, (d) describe the extent of citizens' willingness to pay for improvements in waste management in the city and (e) explore avenues for sustainable financing of municipal solid waste management in Nepal for enhancing urban resilience and adapting to the changing climate. For detailed analysis of these issues, readers are advised to refer to Rai et al. (2019); Bharadwaj, Baland, and Nepal (2020); Nepal et al. (2020); Nepal et al. (2021); and Pervin et al. (2020).

\subsection{Study Area and Data}

This case study is based on the Bharatpur Metropolitan City (BMC), located in the southern plains of Nepal. Bharatpur is a fast growing medium-sized city with

\footnotetext{
${ }^{1}$ https://www.icimod.org/sandee-idrc/.
} 
a population of over 300,000 in its core area. The city is on the bank of a major river, Narayani, which also facilitates the drainage system of the city. There are two supporting natural drainage systems in the city: Pungi $(6.6 \mathrm{~km})$ and Kerunga $(28.4 \mathrm{~km})$ canals. Since the city does not have adequate man-made drainage systems, the encroachment of the natural canals has impacted drainage so that even moderate rainfall results in waterlogging in the city (Pervin et al., 2020).

For the study, we collected different types of data from Bharatpur during 20172018 and complemented it with secondary data. For an understanding of waterlogging and the flooding potential, primary data on rainfall, water level, water discharge, existing drainage networks and their cross sections was collected from the field during the summer of 2017. This information was supplemented by historical hydrological and climate data for developing a mathematical drainage network model (Pervin et al., 2020).

For understanding existing social and behavioural issues and household preferences on solid waste management, we conducted a primary survey of 150 Tole Lane Organizations (TLOs), (small community-level organizations for development activities consisting of 100 households on average, which elect a small executive committee of 9-11 members for addressing community issues including municipal solid waste management.). The 150 TLOs were selected randomly from over 350 TLOs. These TLOs were divided into two groups-control and intervention-for understanding the effectiveness of the interventions. As baseline, we surveyed seven households using systematic random sampling from each TLO (Rai et al., 2019). Altogether 1050 households were surveyed from 14 wards of the city's core area before the intervention. After the intervention, we collected two additional rounds of data from the same households for examining the impact of information campaigns and low-cost waste bins on the streets for keeping the city neighbourhood cleaner. The same baseline survey was used for estimating the value of clean neighbourhoods for Bharatpur. For urban centres across the country, we used a nationally representative household survey (Nepal Living Standards Survey 2010/11). The detailed information is available in Nepal et al. (2020). For sustainable financing of municipal solid waste management, we used information collected by the Asian Development Bank and supplemented it with field data (Bharadwaj, Rai, \& Nepal, 2020).

\subsection{Adapting to Urban Flooding}

Cities in developing countries are particularly susceptible to urban flooding and waterlogging since they have limited drainage infrastructure that is often mismanaged and congested for different reasons including improper disposal of solid wastes in the canals and drains (Haque, 2013). Excessive rainfall exacerbates waterlogging, especially in low-lying areas where slums are generally located in fast growing unplanned cities. Consequently, the groundwater gets contaminated, increasing the likelihood of public health problems (ten Veldhuis et al., 2010). 
Our analysis included rainfall data collected by the Department of Hydrology and Meteorology (DHM) for Bharatpur city at Bharatpur station (from 2000 to 2016), water-level data for the Narayani river at Devghat station and for the Rapti river at Rajayia station collected by the research team. The bankfull levels of the Narayani and Rapti rivers were considered as the design water level for Bharatpur. The surveyed cross sections of the Narayani and Rapti rivers were interpolated to generate bankfull water-level data at the outfalls of the Pungi and Kerunga canals. We used MIKE11 modelling tools from the Danish Hydraulic Institute (DHI) to develop the drainage model. The model was calibrated against the water level and discharge data of the canals for 2017.

We developed some climate change scenarios for Bharatpur based on changing rainfall patterns as the climate change models predict that the volume of rainfall would increase during the monsoon (May-October) and reduce during the dry season (December-March) in the Ganges basin, whereas Bharatpur is one of the sub-basins (Pervin et al., 2020). In the study area, high-intensity and short-duration rainfall is projected to increase, overwhelming the existing drainage infrastructure and resulting in more waterlogging and flooding in future. We also consider the rapid urbanization and land-use change in Bharatpur while developing the model scenarios.

Based on several focus group discussions, we developed the adaptation scenarios for Bharatpur. Under the existing conditions, about 13\% (Fig. 21.1a: Current scenario) of the land area is under the risk of flooding and waterlogging. With appropriate structural interventions, the flooding risks could go down to 5\% (Fig. 21.1b: Improved scenario). These results are shown in Fig. 21.1a and b.

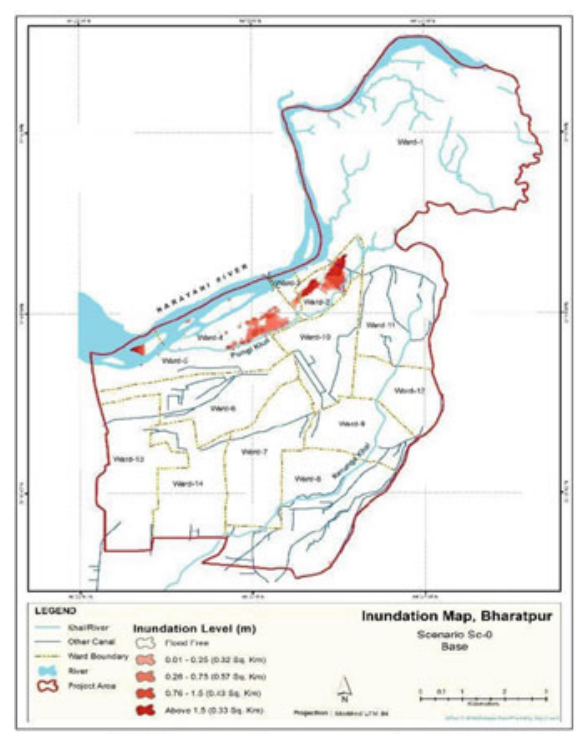

a) Current scenario

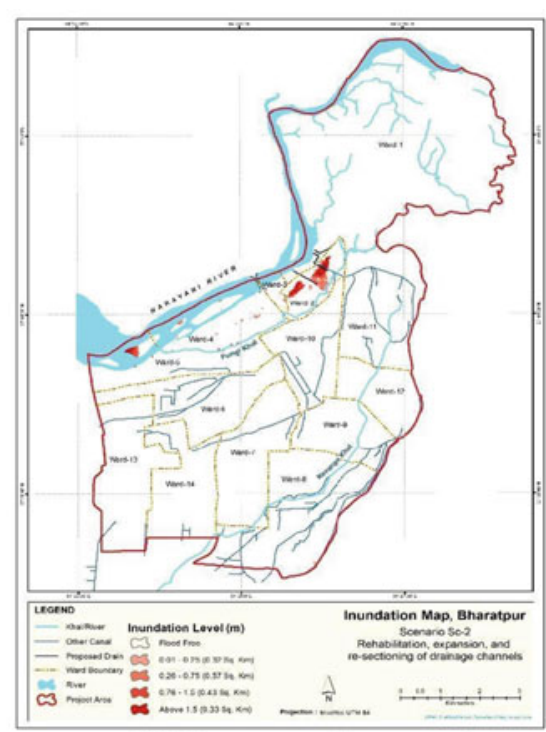

b) Improved scenario

Fig. 21.1 Waterlogging risks with current and improved scenarios. Source Pervin et al. (2020) 
The scenario analysis suggests that without proper solid waste management, the city area at risk of flooding returns to $8 \%$ in five years time, diminishing the returns from investment in physical infrastructure.

\subsection{Effectiveness of Information and Street Bins in Keeping the Neighbourhoods Cleaner}

Since proper solid waste management is the key to reducing flooding and waterlogging risks in the city, we looked at some of the low-cost interventions that would help cities keep neighbourhoods clean. Our intervention involved providing information to the households on how to manage household waste better rather than dumping it or burning it in the intervention TLOs. We also installed street waste bins as part of the intervention. These waste bins are $20 \mathrm{~L}$ bins intended for the people who could put their leftover food and other unwanted items while travelling around the city, but not intended for solid waste generated by the households. For this purpose, we randomly selected two groups of 75 Tole Lane Organizations (TLOs) each, with one designated as a control group for comparison.

After a baseline survey, households and executive committee members of each intervention TLO participated in a workshop which provided information on managing household waste, including segregation, recycling and composting of the waste and why burning or throwing waste is detrimental. We organized one workshop for each intervention TLO. At the same time, 20-litre street waste bins were installed in the intervention TLOs. We conducted a post-intervention survey in the first half of 2018 and a final round of post-intervention survey in the second-half of 2018.

Since we have three rounds of data from each household, we used (a) a simple linear regression model with indicator variables for 'intervention' and 'round' for last two rounds of data (without baseline) and (b) a difference-in-difference approach using all three rounds of data in order to see the impact of intervention on the cleanliness of the neighbourhoods. More specifically, the outcome variables are: cleanliness of the neighbourhood, waste given to the collectors instead of burning or throwing and segregation of the waste at source. Since we use an experimental design to randomly assign control and treatment neighbourhoods, our results have a causal interpretation.

The key findings of the research are summarized below (Nepal, Karki Nepal et al., 2021):

- Neighbourhoods and streets are cleaner due to the intervention: There was a $9 \%$ point increase in the perceived cleanliness of the streets, and 14-22\% point increase in the perceived cleanliness of the neighbourhoods after the intervention.

- More households started giving their wastes to the waste collectors: Due to the intervention, there was an 8-10\% point increase in households that give household waste to the collectors instead of burning or throwing it out. 
- No impact on the at-source segregation: However, our results suggest that there is no impact of the intervention on the at-source segregation of the waste.

Since the intervention was intended to inform households on how to segregate at source and why not to throw or burn the waste, the first two results are expected, but the third result is surprising given that the households had been sensitized how to segregate the waste at source. However, this is possibly due to the fact that there is no provision for collecting degradable and non-degradable wastes separately even though households segregate it at source. In the absence of such separate collection service, households tend to unlearn the learning from the sensitization workshops. Perhaps, if households do not see a likely consequence of their action, they may ignore the instruction or information, suggesting that any programmes or policies should be consequential to the households for them to change their behaviour (Nepal et al., 2009).

\subsection{Households' Preferences for Municipal Solid Waste Management}

The city has been managing solid waste collection through two private companies. They charge monthly fees (ranging from NPR 30 to NPR 100 for the households, and NPR 200 to NPR 4000 for commercial outlets, where the service is based on the volume of waste and frequency of collection). About $95 \%$ of the households in the sampled wards subscribe to the collection service. The city provides additional resources to the private companies since the collected fees do not cover the operational costs. The city also refunds $30 \%$ of the collected fees to the concerned TLOs so that they can invest in cleaning up their communities.

Household survey results suggest that the majority (53\%) of the city residents were not satisfied with the waste collection services that they were getting. This is mainly because they were not getting the services on the given day at a pre-specified time as there was no fixed time or date for picking up the wastes from the households. The private service providers have estimated that only $60 \%$ households pay waste collection tariff regularly. Our choice experiment analysis suggests that households were willing to pay 10-28\% additional fee on top of what they were paying if the service provider collects the waste on a given day and time, and if the city installs waste bins on the streets that pedestrians could use for disposing unwanted litters. This could result in an additional income of NPR 5 million additional for the city. A progressive tariff increase based on the number of floors of the individual houses can generate more revenue, since willingness-to-pay increases by $8.2 \%$ on average for every additional floor of a house (Rai et al., 2019).

Our analysis suggests that the city needs to spend around $17 \%$ additional resources in addition to the existing expenditure in order to provide the expected services (on time collection on a given day and placing bins on the streets) to the city residents. A further $10 \%$ is required for separate collection trips for degradable and 
non-degradable waste. Our analysis suggests that with some additional efforts, the city could meet the expectation of the residents and could collect additional revenues for managing the municipal solid waste better. If all households pay the collection fee as a result of improved services, then the additional collected tariff would outweigh the additional expenditure required for improved services (Table 21.1). In addition, a separate collection service generates additional income from the recycled materials, particularly plastic. This can also lead to increased longevity of landfill sites. Overall, there is some revenue gap under the current system of municipal solid waste management, where composting of organic waste is not considered as an option. When segregation at source promotes composting at home, then waste transportation cost will be reduced from the estimated $10 \%$ since the volume of waste will also decline under this scenario.

In short, city residents are concerned about the municipal solid waste management and willing to pay additional service fee if the current situation improves. For this, the municipality has to improve waste collection service to increase the participation of city residents, for which they are ready to pay additional fees. It is also true that the increased revenue due to the improved services may cover the additional cost, but it is less likely to cover the total cost of municipal solid waste collection services at the existing tariff rate. However, reduced waste due to segregation and longevity of landfill sites increases the social and environmental benefits. We discuss how the revenue shortfall could be overcome in the following section.

Table 21.1 Annual costs and revenue of Bharatpur municipal solid waste management

\begin{tabular}{|c|c|c|c|c|}
\hline \multirow[t]{2}{*}{ S.No. } & \multicolumn{2}{|l|}{ Cost } & \multicolumn{2}{|l|}{ Revenue } \\
\hline & Particular & $\begin{array}{l}\text { Cost (NPR in } \\
\text { millions) }\end{array}$ & Particular & $\begin{array}{l}\text { Revenue (NPR in } \\
\text { millions) }\end{array}$ \\
\hline 1 & $\begin{array}{l}\text { Current operational } \\
\text { cost }\end{array}$ & 39.19 & $\begin{array}{l}\text { Current service fee } \\
\text { collection }\end{array}$ & $18.00-21.60$ \\
\hline 2 & $\begin{array}{l}\text { Improved service } \\
\text { (collection on time) }\end{array}$ & 6.54 & $\begin{array}{l}\text { If all residents pay, } \\
\text { additional revenue }\end{array}$ & 14.40 \\
\hline 3 & $\begin{array}{l}\text { Improved service } \\
\text { (collection of } \\
\text { degradable and } \\
\text { non-degradable } \\
\text { separately) }\end{array}$ & 4.09 & $\begin{array}{l}\text { Additional payment } \\
\text { for waste bins and on } \\
\text { time service }\end{array}$ & $0.60-5.00$ \\
\hline 4 & Total & 49.82 & & $33.00-4100$ \\
\hline
\end{tabular}

Source Field survey $2017-18^{2}$

\footnotetext{
${ }^{2}$ These estimates are based on the field survey 2017-2018, choice experiment analysis, focus group discussion and key-informant interviews with Bharatpur Metro Officials and private companies engaged in waste collection in Bharatpur.
} 


\subsection{Sustainable Financing of Municipal Solid Waste Management}

To examine the revenue potential of materials recovery and recycling for the municipalities in Nepal, we use data collected by the Asian Development Bank in 2013 from 58 municipalities across the country.

Based on existing solid waste management across the municipalities, we examine the materials recovery and recycling rates of plastics, papers and other wastes. We focus mainly on plastic wastes as discarded plastic remains in the environment for a long time and harms the whole ecosystem-land, rivers and oceans. Although plastic bags ban policy with sufficient penalty and strict enforcement can reduce the use of plastic bags, it cannot address the increasing use of plastic for other purposes (Bharadwaj, Baland, \& Nepal, 2020). Plastic-related waste constitutes about $10 \%$ of household solid waste. Under different scenarios, we find that recovered plastic ranges from 0.36 to $1.62 \%$ of total solid waste produced in Nepal. Under the optimistic solid waste management scenario-where the plastic material recovery rate is $15 \%$ and the collection efficiency is $66.7 \%$, the revenue generated from recycling plastic waste-where price of recovered plastic is NPR 30 per $\mathrm{kg}$ and solid waste management costs is NPR 2347 per ton-covers $138 \%$ of the management costs of the plastic-related waste and prevents $4220 \mathrm{t}$ of plastic entering the environment annually in the form of solid waste. Figure 21.2 exhibits the mechanism of the plastic recovery and recycling market. However, under the more practical scenario (average

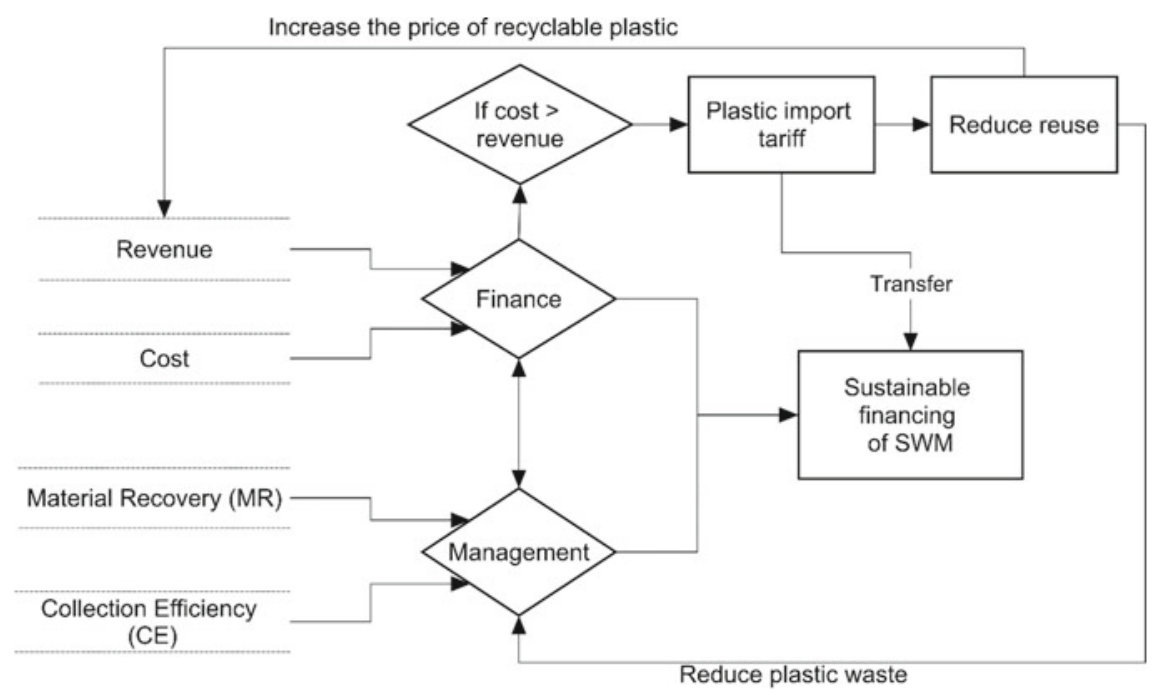

Fig. 21.2 A framework for sustainable financing of municipal solid waste management. Source Bharadwaj, Rai, and Nepal (2020) 
of best and worst cases), the revenue generated from recycling plastic covers only $82.85 \%$ of the plastic-related waste management cost.

Since there would be a resource gap under this scheme for financing plastic waste management, we also estimated an appropriate tariff rate on importing plastic items (including plastic granules and other raw materials) that could help finance the plastic waste management across the country. Our estimate suggests that an additional tariff of $1 \%$ on the imported plastic materials would generate enough revenue for financing the cost of managing plastic wastes (Bharadwaj, Rai, \& Nepal, 2020).

The additional tariff would not only generate required revenue for managing plastic waste, but would also reduce the use of plastic items by making them costlier, thus spurring the demand for recycled plastic in one hand also promoting the alternatives to plastic on the other. The incentive for recycling will reduce the plastic material in the waste stream, which would otherwise end up being released into the environment given the weak dumping site management which results in waste being dumped in the forest or on the riverbanks.

\subsection{Value of Cleaner Neighbourhood}

Improper management of municipal solid waste not only contaminates groundwater and impacts health but it also diminishes the aesthetic value of neighbourhoods and lowers the value of housing property. In general, the price of a housing unit depends on several factors called attributes. Three main categories of the attributes are considered valuable while buying a housing unit. They are structural (land areas, built-up areas, types of roof, wall and floor materials, number of rooms and bathrooms and floors, etc.), neighbourhood (crime rate, school quality and distance, distance to the markets and hospital) and environmental (presence of open space and parks, distance from the forest and rivers, distances from the waste dumping sites and presence of waste collection services) characteristics. Even though these characteristics are important, the buyers may not pay separate prices for each of these attributes as a housing unit is a bundle of all these attributes. We have used the Hedonic price model to disentangle the value of each attribute and examine the effects of municipal solid waste collection services at the neighbourhood level on housing property values (Nepal et al., 2020).

For this purpose, we used two sets of data-one is collected from Bharatpur and the other is collected by the Nepal Central Bureau of Statistics (the third wave of the Nepal Living Standards Survey 2010/11). Hedonic studies in developed countries use market transaction data of housing units. However, market transaction data in Nepal generally understates the housing property price as buyers and sellers have all kinds of incentives to underreport property prices for avoiding taxes unless the buyer gets credit from a bank while buying a house. Therefore, we use self-reported housing values from both sets of data. The study sites are indicated in Fig. 21.3, where red colour indicates Bharatpur Metro, and blue colour indicates other municipalites (2011 Nepal Census). 


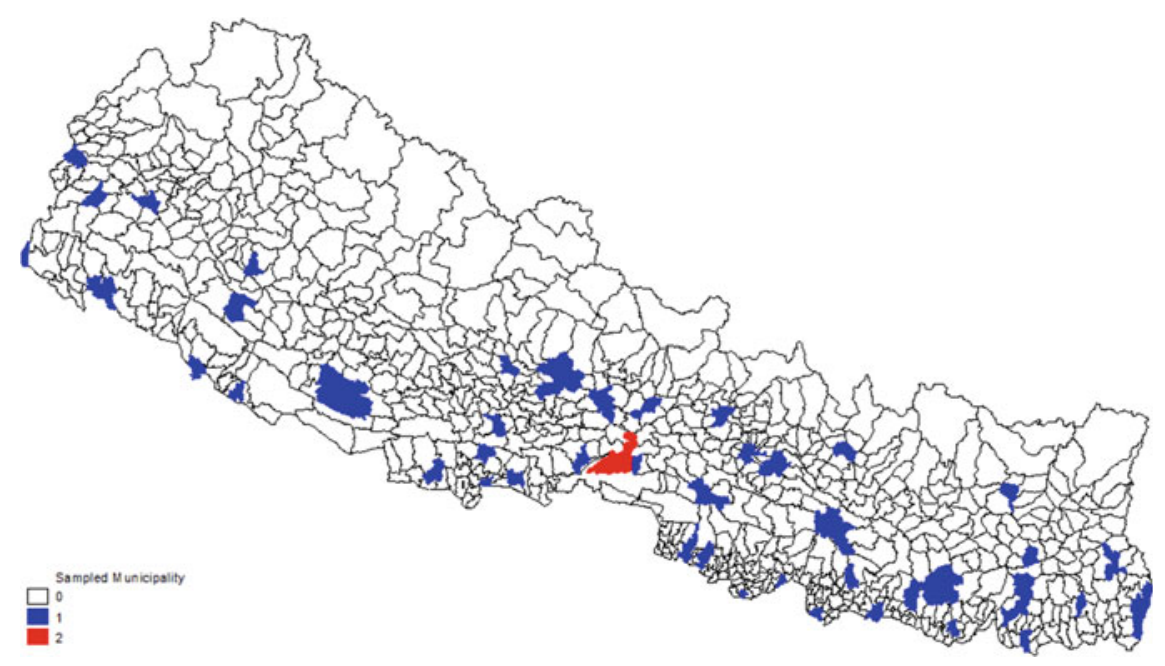

Fig. 21.3 Sampled municipalities across the country. Source Nepal et al. (2020)

We estimated the implicit price of presence of solid waste management service, a proxy for cleaner neighbourhood, in three market segments-urban hills, urban Terai and Bharatpur. We found that in these market segments, the housing price could be 25-57\% higher in communities where solid waste management services are in place while the housing price could be $11 \%$ lower in a community where there are open drains nearby (Nepal et al., 2020). That is, city residents place a high price premium on cleaner neighbourhoods and a price penalty when the drainage system is open.

Figure 21.4 indicates that the housing price could be greatly enhanced with the provision of municipal solid waste management in the community. Hence, making solid waste management a top priority is rewarding not only to the home owners but also to the cities where the tax base includes the assessed value of property, and a part of the tax revenue could be used to finance the revenue shortfall for managing municipal solid waste better.

\subsection{Discussion and Conclusion}

This chapter highlights some of the key findings from a large-scale research project, and the detailed methods and results are published in several papers (Rai et al., 2019; Bharadwaj, Rai, \& Nepal, 2020; Nepal et al., 2020; Nepal et al., 2021; Pervin et al., 2020; Nepal, Karki Nepal et al., 2021). Flooding is a major hazard for cities like Bharatpur, and this problem will become more serious with climate change, requiring improved drainage systems. This involves not only an improvement in the physical infrastructure of canals and drains but also in solid waste management to 


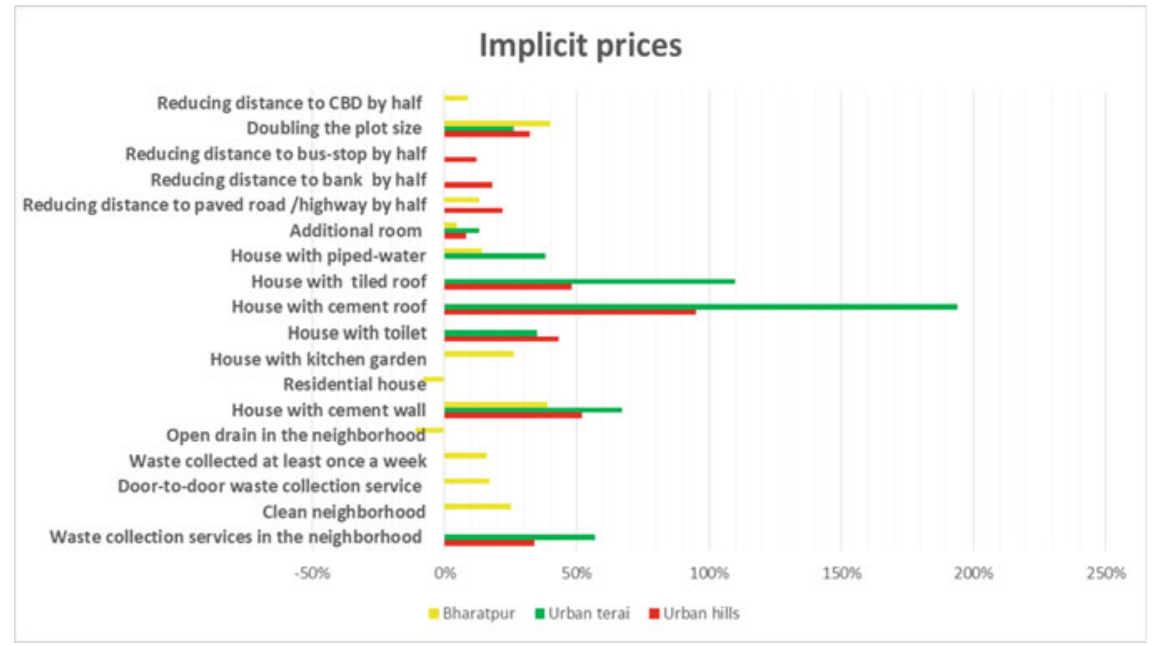

Fig. 21.4 Implicit prices of the housing attributes. Source Authors' calculation

prevent clogging of the drainage network. The latter requires the involvement of the communities.

In the case of Bharatpur, while physical investment in drainage systems is estimated to reduce the flood-prone area by $38 \%$ (comes down to $5 \%$ from $13 \%$ ), improved waste management is estimated to reduce it by an additional $37 \%$ (prevents going back to $8 \%$ flood-prone area from $5 \%$ ). Women tend to manage household solid waste better in terms of segregation and composting that reduces the volume of waste going to landfill sites, suggesting that targeted sensitization programmes would help making the communities cleaner and less prone to waterlogging (Nepal et al., 2021; Rakib et al., 2022, Chap. 24 of this volume).

The randomized intervention consisting of provision of information and sensitization to waste management as well as provision of street bins resulted in cleaner streets and neighbourhoods and more waste being given to collectors rather than being dumped nearby or burnt. However, segregation at source did not improve probably because residents did not perceive it as being effective in the absence of a system for collecting segregated waste separately by the collection service.

At present, as in most cities in low-income countries, the revenue from municipal waste collection fees in Bharatpur is insufficient to cover the cost of collection and disposal. This makes it difficult to improve solid waste management. However, our analysis of household survey data shows that people are willing to pay more for better service. This can partially close the revenue gap. Additional revenue could be raised by recycling plastic materials and increasing the tariff on imported plastic in Nepal by a modest $1 \%$. This would raise sufficient revenue for managing plastic wastes.

A further avenue for raising revenue to cover waste management costs that promotes adapting to climate change in the cities for enhancing urban resilience arises from the effect that cleaner neighbourhoods seem to have on housing prices. 
If some of this increase in pricing of houses is captured by the municipalities through an increase in revenue from property taxes, then this would easily bring in enough revenue to finance the necessary improvements in municipal solid waste management.

Acknowledgements The authors gratefully acknowledge the International Development Research Center (IDRC), Ottawa, Canada for providing financial support (Grant \#08283-001) under the Cities and Climate Change research (2017-2020) to conduct this study. The International Centre for Integrated Mountain Development (ICIMOD), where the first author is affiliated, acknowledges with gratitude the support of the Governments of Afghanistan, Australia, Austria, Bangladesh, Bhutan, China, India, Myanmar, Nepal, Norway, Pakistan, Sweden, and Switzerland. However, the views as well as interpretations of the results presented in this research are those of the authors and should not be attributed to their affiliated organizations, their supporters or the funding agency.

\section{References}

Ahmed, I. (2016). Building resilience of urban slums in Dhaka, Bangladesh. Procedia-Social and Behavioral Sciences, 218, 202-213.

Bharadwaj, B., Baland, J. M., \& Nepal, M. (2020). What makes a ban on plastic bags effective? The case of Nepal. Environment and Development Economics, 25(2), 95-114.

Bharadwaj, B., Rai, R. K., \& Nepal, M. (2020). Sustainable financing for municipal solid waste management in Nepal. PLOS One, 15(8), e0231933.

Haque, A. K. E. (2013). Reducing adaptation costs to climate change through stakeholder-focused project design: The case of Khulna city in Bangladesh (No. G03520). International Institution for Environment and Development. http://pubs.iied.org/G03520/?k=enamul.

Haque, A. E., Lohano, H. D., Mukhopadhyay, P., Nepal, M., Shafeeqa, F., \& Vidanage, S. P. (2019). NDC pledges of South Asia: Are the stakeholders onboard? Climatic Change, 155(2), 237-244.

Nepal, M., Berrens, R. P., \& Bohara, A. K. (2009). Assessing perceived consequentiality: Evidence from a contingent valuation survey on global climate change. International Journal of Ecological Economics and Statistics, 14(P09), 14-29.

Nepal, M., Rai, R. K., Khadayat, M. S., \& Somanathan, E. (2020). Value of cleaner neighbourhoods: Application of hedonic price model in low income context. World Development, 131, 104965.

Nepal, M., Cauchy, M., Karki Nepal, A., \& Gurung Goodrich, C. (2021). Household waste management and the role of gender in Nepal. In A. Achaarya (ed.). Environmental Economics in Developing Countries: Issues and Challenges (forthcoming), Routledge.

Nepal, M., Karki Nepal, A., Khadayat, M. S., Pervin, I. A., Rai, R. K., \& Somanathan, E. (2021). Low-cost strategies to improve municipal solid waste management in developing countries Learning from an experiment in Nepal. Working Paper, SANDEE, Kathmandu, Nepal.

Pervin, I. A., Rahman, S. M. M., Nepal, M., Haque, A. K. E., Karim, H., \& Dhakal, G. (2020). Adapting to urban flooding: A case of two cities in South Asia. Water Policy, 22(S1), 162-188.

Rai, R. K., Nepal, M., Khadayat, M. S., \& Bhardwaj, B. (2019). Improving municipal solid waste collection services in developing countries: A case of Bharatpur Metropolitan City, Nepal. Sustainability, 11(11), 3010.

Rakib, M., Hye, N., \& Haque, A. K. E. (2022). Waste segregation at source: A strategy to reduce waterlogging in Sylhet. In A. K. E. Haque, P. Mukhopadhyay, M. Nepal, \& M. R. Shammin (Eds.), Climate change and community resilience: Insights from South Asia. Springer.

Sharma, U., Brahmbahtt, B., \& Panchal, H. N. (2022). Do community-based institutions spur climate adaptation in urban informal settlements in India? In A. K. E. Haque, P. Mukhopadhyay, 
M. Nepal, \& M. R. Shammin (Eds.), Climate change and community resilience: Insights from South Asia. Springer.

ten Veldhuis, J. A. E., Clemens, F. H. L. R., Sterk, G., \& Berends, B. R. (2010). Microbial risks associated with exposure to pathogens in contaminated urban flood water. Water Research, 44(9), 2910-2918.

Open Access This chapter is licensed under the terms of the Creative Commons AttributionNonCommercial-NoDerivatives 4.0 International License (http://creativecommons.org/licenses/bync-nd/4.0/), which permits any noncommercial use, sharing, distribution and reproduction in any medium or format, as long as you give appropriate credit to the original author(s) and the source, provide a link to the Creative Commons licence and indicate if you modified the licensed material. You do not have permission under this licence to share adapted material derived from this chapter or parts of it.

The images or other third party material in this chapter are included in the chapter's Creative Commons licence, unless indicated otherwise in a credit line to the material. If material is not included in the chapter's Creative Commons licence and your intended use is not permitted by statutory regulation or exceeds the permitted use, you will need to obtain permission directly from the copyright holder.

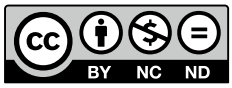

